\title{
Covid-19: Failure to control pandemic and inequalities made England worst affected in Europe, says report
}

Shaun Griffin

A failure to control the coronavirus pandemic, coupled with widening inequality over the past decade, has led to England having the highest rate of excess deaths from covid-19 in Europe, a new report concluded. ${ }^{1}$ Rather than focusing on narrow economic goals, health and wellbeing should be at the heart of government strategy, it says.

The findings and recommendations from the report by Michael Marmot, director of University College London's Institute of Health Equity, add to those made in a 10 year update, published in February, ${ }^{2}$ of the landmark 2010 Marmot review of strategies for reducing health inequality. The update showed that England was entering the pandemic in a poor state of health, with life expectancies in its most deprived areas declining and a slower improvement in overall life expectancy than in almost any other rich nation.

At a press conference to launch his latest report, Marmot said, "The key finding is that the health and social inequalities affecting covid-19 mortality almost exactly parallel those seen for all causes of death. Covid-19 has affected every stage of the life course."

The pandemic has adversely affected young people's social and emotional development, with the closure of schools and early years settings increasing an already wide educational gap, said the report. Among ethnic minority communities, systemic disadvantages-such as overcrowded living conditions, declining housing quality, and higher exposure to the virus at work and at home ${ }^{3}$-contributed to the "shockingly high" number of covid-19 deaths in these groups, it added. "We should deal with the structural racism [that causes this]," Marmot said.

He also warned that the effects of lockdown and other containment measures, such as reduced family income and damage to young people's physical and mental health as well as their employment prospects, would serve only to widen inequalities in the long term.

The report made a series of recommendations to overcome inequalities amplified by the pandemic in the short term, to tackle deteriorating socioeconomic conditions in the medium term, and to create a cohesive society in the long term. In the area of prevention, for example, it recommended increasing public health funding to $0.5 \%$ of GDP (from $0.15 \%$ ) and developing a public health system that focused more on living and working conditions.

\section{New government strategy vital}

"If, as we argue, health is a measure of how well society is meeting the needs of its members, then the UK's poor management of the pandemic may similarly be a marker of a society that is not functioning in a socially cohesive and supportive fashion," the report said.

Marmot added, "It would be a tragic mistake to attempt to re-establish the status quo that existed before the pandemic. There is an urgent need to do things differently: to build a society that functions to meet the needs of its members; to build a wellbeing economy that puts achievement of health and wellbeing at the heart of government strategy, rather than narrow economic goals; and to build a society that responds to the climate crisis at the same time as achieving greater health equity."

He also reiterated his call made in February that action on climate should be delivered through a national strategy led by the prime minister, calling this a "vital step."

"The government was totally distracted by covid-19 after publication of the February report, and there was no indication that they were taking it seriously," said Marmot. "They should have seen growing inequalities and the worsening health for the poorest people as a crisis. I would hope that they will now take this seriously and start to engage with the recommendations."

He added, "After the pandemic [struck] the prime minister said 'no more austerity' and the chancellor said 'whatever it takes.' I think that should be the approach now."

As well as citing the importance of engaging with communities in driving change, in terms of the NHS response Marmot said he was "hugely encouraged that the Royal College of Physicians set up a health inequalities alliance, which now has more than 100 members."

Institute of Health Equity. Build back fairer: the covid-19 Marmot review. Dec 2020. http://www.instituteofhealthequity.org/about-our-work/latestupdates-from-the-institute/build-back-fairer.

2 lacobucci G. Marmot 10 years on: austerity has damaged nation's health, say experts. BM/2020;368:m747. doi: 10.1136/bmj.m747 pmid: 32098785

3 lacobucci G. Covid-19: Increased risk among ethnic minorities is largely due to poverty and social disparities, review finds. BMJ 2020;371:m4099. doi: 10.1136/bmj.m4099 pmid: 33093063

This article is made freely available for use in accordance with BMJ's website terms and conditions for the duration of the covid-19 pandemic or until otherwise determined by BMJ. You may use, download and print the article for any lawful, non-commercial purpose (including text and data mining) provided that all copyright notices and trade marks are retained. 